\title{
KOREKSI KETINGGIAN TEMPAT TERHADAP FIKIH WAKTU SALAT: Analisis Jadwal Waktu Salat Kota Bandung
}

\author{
Encep Abdul Rojak ${ }^{1}$, Amrullah Hayatudin ${ }^{2}$, Muhammad Yunus ${ }^{3}$ \\ Universitas Islam Bandung (Unisba), Bandung \\ e-mail: ${ }^{1}$ abd.rozaq19@gmail.com; ${ }^{2}$ amrullahhayatudin@gmail.com; \\ 3yunus_rambe@yahoo.co.id
}

\begin{abstract}
Prayer time is locality in accordance with geographic data. For one geographical data will result one of prayer time. But there are different things with this general rule, namely the phenomenon of maghrib twice during Ramadan 1437 H. / 2016 M. in Bandung. There are two prayer schedule format that developed at that time, which is schedule issued by the Ministry of Religious West Java Regional Office (Kemenag) and schedule sourced by online of the Central of Ministry of Religious Affairs. Bandung has elevated above 600 meters mean sea level, but not located on the beach. Such circumstances make different ijtihad scholars of elevation data in the calculation of the prayer times. According to scholars of the city, Bandung has a elevation above 600 meters mean sea level, in the calculation of the maghrib prayer time must take into calculation the height of the place. This is to get results that match the real conditions. Kemenag and BHRD West Java using real data in the calculation of prayer times. This schedule is much used as a reference by mosques such as the Great Mosque of al-Ukhuwah Bandung, Mosque PUSDAI, Trans Studio Mosque Bandung, and Masjid Istiqomah Bandung.
\end{abstract}

Awal waktu salat bersifat lokalitas sesuai dengan data geografis. Untuk satu data geografis akan menghasilkan satu waktu salat. Namun ada hal yang berbeda dengan kaidah umum ini, yaitu terjadi fenomena adzan maghrib dua kali pada saat Ramadhan 1437 H. / 2016 M. di Kota Bandung. Ada dua format jadwal salat yang berkembang saat itu, yaitu jadwal yang dikeluarkan oleh Kemenag Kanwil Jawa Barat dan jadwal yang bersumber dari sistem online Kementrian Agama Pusat. Diantara jadwal tersebut, ada yang menggunakan data ketinggian tempat dan ada pula yang mengabaikannya. Bandung memiliki ketinggian tempat di atas 600 meter dpl, namun tidak terletak di sisi pantai. Keadaan seperti ini menjadikan ulama ilmu falak berbeda ijtihad dalam penggunaan data ketinggian tempat dalam perhitungan awal waktu salat magrib. Menurut ulama falak, kota Bandung yang memiliki ketinggian tempat di atas 600 meter dpl, dalam perhitungan awal waktu salat Magrib harus memperhitungkan ketinggian tempat. Hal ini untuk mendapatkan hasil yang sesuai dengan kondisi real di lapangan. Kemenag dan BHRD Jawa Barat menggunakan data real dalam perhitungan awal waktu salat. Jadwal ini banyak dijadikan acuan oleh masjid-masjid yang besar seperti Masjid Agung al-Ukhuwah Bandung, Masjid PUSDAI, Masjid Agung Trans Studio Bandung, dan Masjid Istiqomah Bandung.

Keywords: waktu salat; ketinggian tempat; masjid 


\section{Pendahuluan}

Terdapat lima waktu salat wajib bagi umat Islam seluruh dunia. Masingmasing waktu salat tersebut memiliki batasan-batasan waktu tersendiri dan akan saling sambut menyambut waktu, misalkan waktu Zuhur habis disambut waktu Asar tanpa ada jeda, waktu Asar habis disambut waktu Magrib tanpa ada jeda waktu, setelah waktu Magrib habis disambut dengan waktu Isya tanpa ada jeda waktu yang memisahkan, setelah habis waktu Isya akan disambut dengan waktu subuh sampai dengan terbitnya matahari, dan akan kembali disambut waktu Zuhur setelah ada jeda dari terbit matahari sampai dengan titik kulminasi atas matahari. Batasan masing-masing waktu ini merupakan ketentuan dari Allah yang disampaikan dalam al-Qur'an dan hadis Rasulullah yang telah menjelaskan lebih rinci waktu-waktu salat.

Waktu salat akan berlaku secara lokalitas berdasarkan data lintang dan bujur yang diinput dalam perhitungan awal waktu salat, dan akan berlaku berdasarkan waktu perhitungannya merujuk kepada tanggal, bulan, dan tahun perhitungan. Jakarta akan memiliki jadwal salat tersendiri dan akan berbeda dengan Bandung, karena keduanya memiliki data geografis yang berbeda. Begitu juga Semarang dengan Surabaya, keduanya akan memiliki jadwal salat tersendiri dan akan berlaku secara lokal. Bagi setiap tempat, seperti Jakarta, Bandung, Semarang, dan Surabaya akan memiliki satu jadwal waktu salat yang berlaku untuk daerah tersebut, dan tidak akan memiliki dua ketetapan dan jadwal waktu. Hal ini merupakan sebuah keseragaman dan mewujudkan kenyamanan bagi masyarakat dalam melaksanakan ibadah.

Ada yang berbeda dengan teori umum tentang lokalitas jadwal waktu salat, yaitu terjadi di kota Bandung. Pada saat Ramadhan 1437 H. / 2016 M., terjadi fenomena yang sangat membingungkan masyarakat Bandung, yaitu terjadi dua waktu berbuka puasa di Bandung. Sebagaimana sebuah artikel yang ditulis oleh wartawan senior di rubrik "Opini Pikiran Rakyat". ${ }^{1}$ Ia menjelaskan bahwa khusus untuk waktu Magrib, kumandang adzan di bulan Ramadhan 1437 H. itu terdapat dua kali, yang berkembang di media elektronik

1Muhammad Ridlo Eisy, Opini Pikiran Rakyat, 15 Juni 2016, h. 26. 
seperti Televisi daerah dan radio. Namun kekeliruan ini sangat fatal, karena umat Islam dalam rujukan berbuka puasa lebih kepada media elektronik daripada media cetak. Selisih antara dua adzan tersebut tergolong besar yaitu sekitar 4 menit. Jumlah ini dalam keadaan menunggu untuk berbuka bukanlah waktu yang sebentar, tetapi waktu yang lama dan sangat mengkhawatirkan.

Pada saat itu, setidaknya terdapat dua format jadwal waktu salat yang dijadikan rujukan oleh masyarakat, khususnya media elektronik seperti televisi dan radio. Jadwal pertama adalah jadwal yang berbentuk print out yang dikeluarkan oleh Kementrian Agama (Kemenag) Jawa Barat yang bekerja sama dengan Badan Hisab dan Rukyat Daerah (BHRD) Jawa Barat. Jadwal ini dibagikan oleh Kemenag ke beberapa masjid dan media massa, seperti TVRI dan koran Pikiran Rakyat. Selain disebarluaskan berupa hasil percetakan, Kemenag juga mengupload data ini di internet dengan format gambar / Jpg bukan aplikasi. Sehingga masyarakat bisa terbantu untuk mendapatkan jadwal salat khusus Ramadhan untuk kota Bandung.

Jadwal kedua yang berkembang di Bandung saat itu adalah jadwal yang bersumber dari Kementrian Agama (Kemenag) Pusat RI. Melalui sistem yang dibuat secara online bernama Sistem Informasi Hisab Rukyat Indonesia (SIHAT), umat Islam yang berada di manapun dapat mengambil jadwal dari sistem ini. Dengan cara membuka alamatnya di mesin pencari online yaitu http://sihat.kemenag.go.id/waktu-sholat, ${ }^{2}$ kemudian memilih Provinsi, Kota dan Bulan dan tahun yang dimaksud, setelah itu kemudian klik tampilkan jadwal salat, maka sistem akan mengeluarkan jadwal waktu salat sesuai dengan pilihan yang sudah disiapkan. Sistem ini memberikan pelayanan yang lebih mudah, sehingga banyak media eletronik yang mengambil jadwal dari sistem ini dan menjadikannya sebagai acuan dalam masuknya waktu salat. Selain itu, perkembangan dunia digital menjadikan waktu salat sangat mudah dicari, seperti aplikasi waktu salat android yang sudah banyak berkembang. ${ }^{3}$ Dan ini biasanya menjadi salah satu rujukan umat Islam dalam masuknya awal waktu salat. Selain itu, terkadang di beberapa masjid juga terdapat jadwal salat

\footnotetext{
2 http://sihat.kemenag.go.id/waktu-sholat diakses pada 29 Agustus 2016.

3Muhammad Nashiruddin Darajat, Abdul Fadlil, Sunardi, "Sistem Informasi Arah Kiblat dan Jadwal Waktu Salat Berbasis Android", Jurnal Teknologi, Volume 9, Nomor 2, Desember 2016, h. 148.
} 
abadi yang tidak pernah di-update dan berlaku selamanya. Ini menjadi khazanah tersendiri dalam jadwal waktu salat dan menjadi warna tersendiri dari jadwal yang berkembang di masyarakat. ${ }^{4}$

Terdapat perbedaan masuknya awal waktu salat dalam jadwal tersebut, khususnya awal waktu Magrib. Jadwal yang bersumber dari Kemenag Jawa Barat waktu salat Magribnya lebih akhir daripada jadwal pembandingnya, selisihnya sekitar 4 menit. Sedangkan jadwal yang bersumber dari sistem Kemenag RI menunjukkan waktu Magrib lebih awal daripada pembandingnya. Magrib merupakan salah satu waktu salat wajib bagi umat Islam. Khususnya di bulan Ramadhan, waktu salat ini bukan hanya menandakan masuknya kewajiban untuk melaksanakan salat Magrib, namun menjadi acuan juga dalam mengakhiri pelaksanaan ibadah puasa bagi yang melaksanakannya. Perbedaan 1 menit saja sudah harus diselesaikan dan dapat membingungkan masyarakat, serta dapat mengancam keabsahan puasanya.

Setiap jadwal yang berkembang ini memiliki dasar perhitungan yang sedikit berbeda. Jadwal yang bersumber dari Kemenag Jawa Barat menggunakan input data secara real kota Bandung, yaitu memperhitungkan data lintang tempat, bujur tempat, serta data ketinggian tempat dihitung di atas permukaan laut (dpl), khususnya awal waktu salat Magrib. Di luar waktu Magrib, proses perhitungan waktu salat lainnya tidak memerlukan elevasi. Namun perhitungan yang didasarkan kepada perhitungan real ini tidak serta merta diikuti oleh jadwal yang bersumber dari sistem SIHAT Kementerian Agama RI. Jadwal salat berupa program ini menggunakan data lintang dan bujur secara umum saja, dan tanpa memperhitungkan data ketinggian tempat. ${ }^{5}$ Akibatnya akan terdapat selisih antara beberapa waktu salat. Untuk awal waktu salat Isya, Subuh, Duhur, dan Asar, permulaan waktunya relatif sama dan tidak akan ditemukan selisih yang signifikan. Namun untuk awal waktu Magrib, selisih dalam mengawali waktunya akan terlihat signifikan.

4Jayusman, "Jadwal Waktu Salat Abadi", Khatulistiwa: Journal of Islamic Studies, Volume 3, Nomor 1, Maret 2013, h. 56.

5Wawancara dengan Fajar Fathurrohman, pada acara pelatihan bagi Guru Pendidikan Agama Islam tingkat SMP dan SMA se-Kota Bandung, dilaksanakan oleh Badan Hisab Rukyat Kota Bandung, Rabu, 26 Oktober 2016. 


\section{Landasan Normatif Waktu Salat}

Islam memiliki konstelasi hukum yang melekat bagi setiap pemeluknya. Dimana pun ia berada, kewajiban ini harus dilaksanakan dalam setiap perbuatannya. Hukum-hukum yang berkenaan dengan perbuatan manusia merujuk kepada empat sumber, ${ }^{6}$ yaitu: 1) al-Qur'an; 2) al-Sunnah; 3) Ijma'; 4) Qiyas.

Berkaitan dengan landasan awal waktu salat, Allah telah mengatur ketentuannya di dalam al-Qur'an, yang dijelaskan lebih luas di dalam as-Sunnah. Salat merupakan salah satu rukun Islam yang tidak bisa diwakilkan dalam pelaksanaannya, tidak bisa dipindahkan dalam waktunya, dan harus dilaksanakan sesuai dengan waktunya. Berikut ini landasan waktu salat yang telah diatur dalam al-Qur'an dan as-Sunnah.

Firman Allah dalam surat al-Nisā, ayat 103:

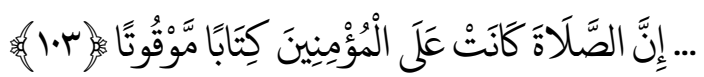

“... Sesungguhnya salat itu adalah fardhu yang ditentukan waktunya atas orang-orang yang beriman."

Firman Allah dalam surat Tāhā, ayat 130:

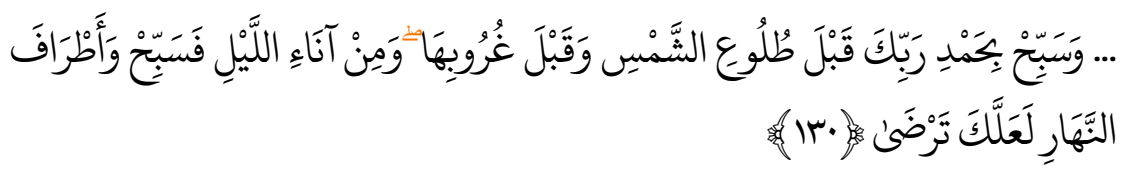

“... dan bertasbihlah dengan memuji Tuhanmu, sebelum terbit matahari dan sebelum terbenamnya dan bertasbih pulalah pada waktu-waktu di malam hari dan pada waktu-waktu di siang hari, supaya kamu merasa senang."

Ayat ini memberikan gambaran bahwa waktu salat umat Islam berjumlah lima waktu dalam sehari semalam. Makna tasbih berarti salat yang dilaksanakan sebelum terbit matahari, yaitu salat Subuh yang mensyaratkan pelaksanaannya tidak boleh lebih dari terbitnya matahari. Salat yang dilaksanakan sebelum matahari terbenam, yaitu dilaksanakan pada waktu sore hari. Ada dua waktu salat yang dimaksud redaksi ini yang dilaksanakan sebelum matahari terbenam yaitu salat Duhur dan Asar. Pada waktu malam hari ter-

6Abdul Wahhab Khallaf, Ilmu Ushul Fiqh (Semarang: Dina Utama, t.th), h. 13. 
dapat waktu salat yang harus dilaksanakan oleh setiap Muslim. Dua waktu salat secara berurutan adalah Magrib dan Isya. Semua waktu salat ini harus dilaksanakan tepat pada waktunya, tidak boleh lebih atau kurang.7

Firman Allah dalam surat al-Isrā ayat 78:

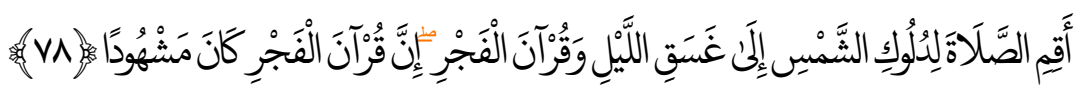

"Dirikanlah salat dari sesudah matahari tergelincir sampai gelap malam dan (dirikanlah pula salat) Subuh. Sesungguhnya salat Subuh itu disaksikan (oleh malaikat)."

Firman Allah dalam surat Hūd ayat 114:

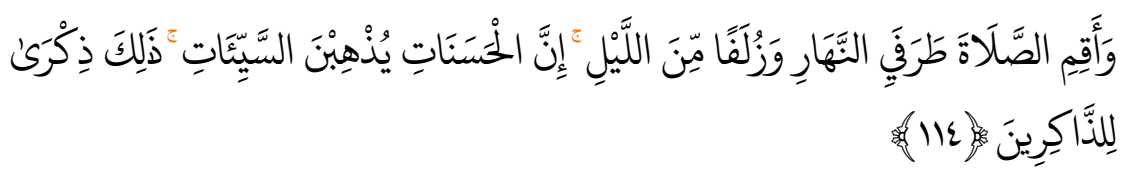

"Dan dirikanlah salat itu pada kedua tepi siang (pagi dan petang) dan pada bagian permulaan daripada malam. Sesungguhnya perbuatan-perbuatan yang baik itu menghapuskan (dosa) perbuatan-perbuatan yang buruk. Itulah peringatan bagi orang-orang yang ingat."

Wahbah al-Zuhaili menafsirkan bahwa ayat ini berkaitan dengan waktu salat bagi umat Islam. Terdapat arti kedua tepi siang, menurut Wahbah al-Zuhaili makna kata ini mengandung waktu salat yang berada di kedua tepi siang, yaitu pagi dan sore. Pada kedua tepi siang ini terdapat tiga waktu salat yaitu salat Subuh, Zuhur, dan Asar. Subuh dilaksanakan sebelum terbit matahari, Zuhur dilaksanakan ketika matahari berada di tengah-tengah hari, dan Asar dilaksanakan pada waktu sore sebelum matahari terbenam. Lafadz yang kedua yang mengisyaratkan waktu salat adalah permulaan daripada malam hari. Waktu malam dimulai dengan terbenamnya matahari, dan pada lafadz ini terdapat dua waktu salat yaitu salat Magrib dan Isya. Magrib dilaksanakan sesaat setelah matahari terbenam dan Isya dilaksanakan pada saat matahari menjauh dari langit barat yang ditandai dengan hilangnya mega merah. ${ }^{8}$

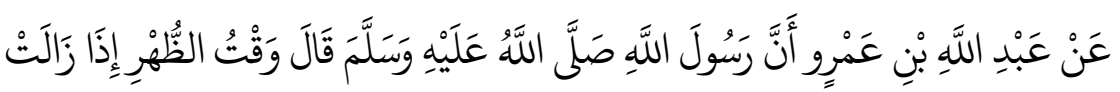

${ }^{7}$ Wahbah al-Zuhaili, al-Tafsir al-Munīr, Jilid VIII (Damsyiq: Dār al-Fikr, 2009), h. 664-665.

8 Ibid, Jilid VI, h. 497. 


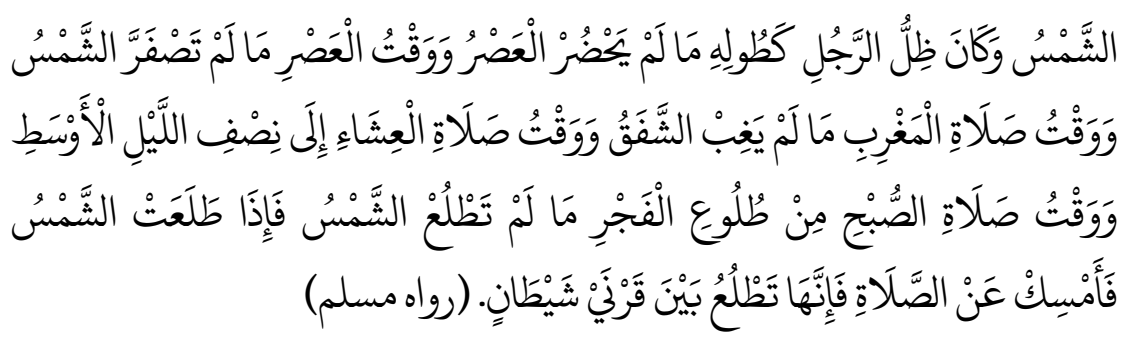

"Dari Abdullah bin 'Amr bahwa Rasulullah bersabda: "Waktu duhur ketika matahari condong (ke Barat) dan bayangan sesorang sama dengan panjangnya selama belum tiba waktu Asar, dan waktu asar itu selama matahari belum menguning, waktu maghrib di saat mega merah (shafaq) belum menghilang, kemudian waktu Isya (dari Magrib) sampai pertengahan malam, dan waktu shubuh dimulai dari terbitnya fajar sampai dengan matahari belum terbit, jika matahari terbit, maka janganlah melaksanakan salat, sebab ia terbit diantara dua tanduk setan." (H.R. Muslim nomor 972).

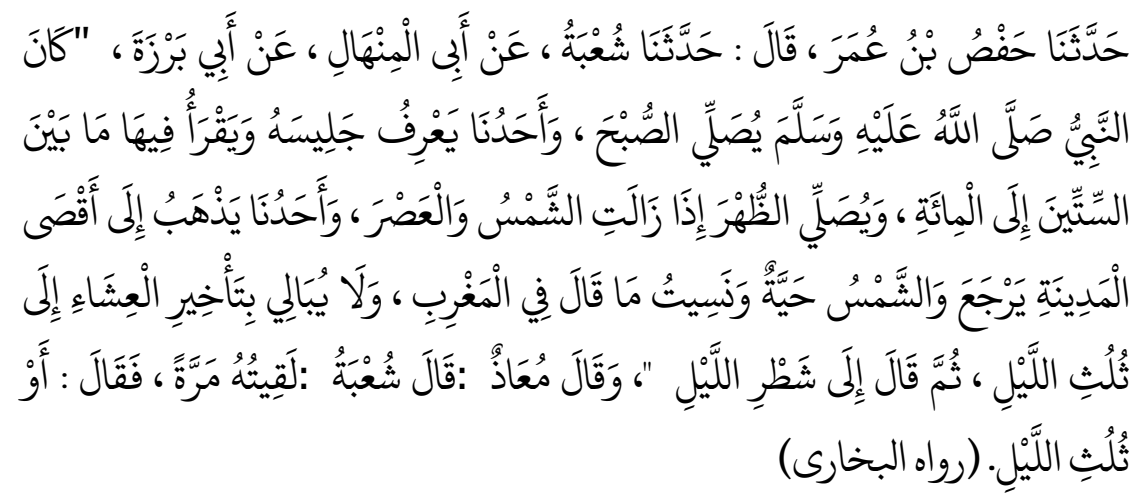

Hafsh bin Umar menyampaikan kepada kami dari Shu'bah, dari Abū alMinhāl, dari Abū Barzah berkata, "Nabi salat Subuh dan setelah salat salah seorang dari kami dapat mengenali orang yang duduk di sampingnya (karena sudah terang). Dalam salat itu, Nabi membaca sekitar 60 sampai 100 ayat al-Qur'an. Nabi juga pernah salat duhur ketika matahari tergelincir, salat Asar pada saat salah seorang dari kami (pergi dan) telah kembali dari tempat terjauh di Madinah dari matahari masih belum berubah warna - (perawi lupa apa yang dikatakan Abū Barzah tentang salat Magrib). Nabi tidak mempermasalahkan untuk mengakhirkan salat Isya sampai sepertiga malam. (Kemudian ia berkata) sampai tengah malam". Mu'ādh meriwayatkan bahwa Shu'bah berkata, "Kemudian aku bertemu dengannya sekali. Dia berkata, atau sepertiga malam". (HR. Bukhari nomor 516)

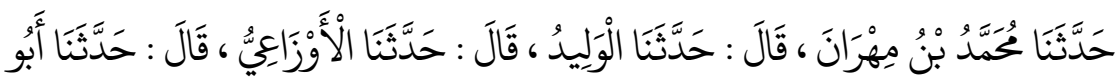




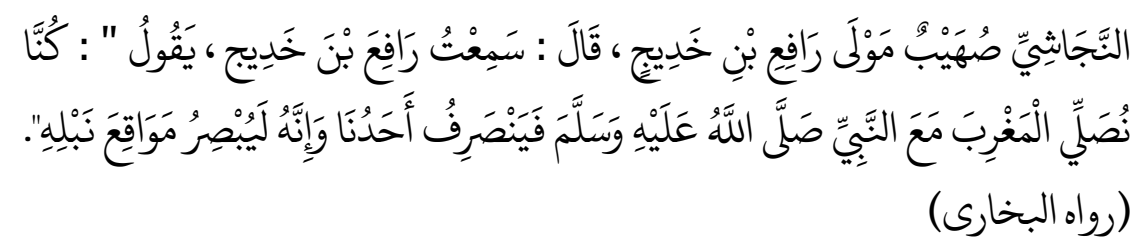

Muhammad bin Mihrām menyampaikan kepada kami dari al-Walīd, dari alAuzāí, dari Abū Najāshi (Atạ̄ bin Șuhaib) Maulā Rāfi' bin Khadīj bahwa dia mendengar Rāfi" bin Khadij berkata, "Kami salat Magrib bersama Nabi. Kemudian salah seorang dari kami keluar lalu melempar anak panahnya, dan dia masih bisa melihat tempat jatuh anak panah tersebut. (HR. Bukhāri nomor 559)

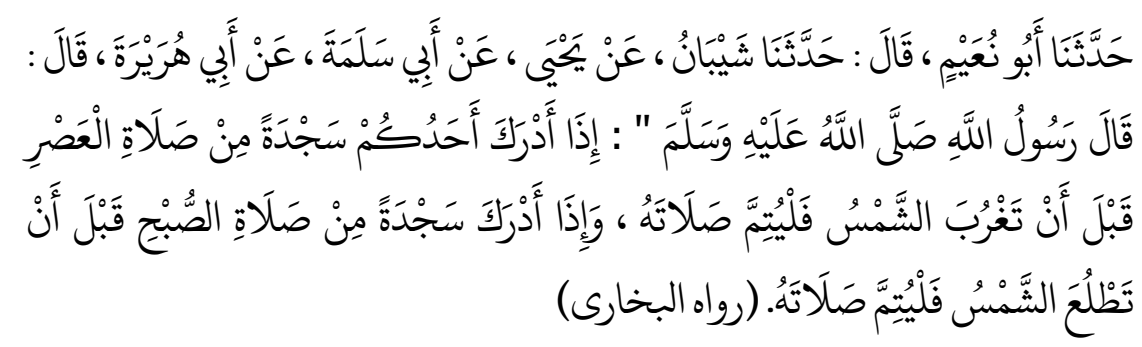

Abū Nu'aim menyampaikan kepada kami dari Syaibān, dari Yahya, dari Abu Salamah dari Abū Hurairah bahwa Rasulullah bersabda: "Jika salah seorang dari kalian mendapatkan satu sujud dalam salat Asar sebelum matahari terbenam, hendaklah ia menyempurnakan salatnya. Jika dia mendapatkan satu sujud dalam salat Subuh sebelum matahari terbit, hendaklah dia menyempurnakan salatnya. (HR. Bukhārī nomor 531)

\section{Kedudukan Matahari dalam Waktu Salat}

Matahari merupakan sebuah bintang yang paling dekat dengan bumi dan menjadi pusat tata surya. Bintang ini menghasilkan energinya sendiri melalui mekanisme reaksi fusi yang terdapat pada intinya. Energi yang ada di dalamnya senantiasa dipancaran ke permukaan sehingga menghasilkan temperatur permukaannya sangat panas. Nilai temperatur permukaan yang dihitung dengan persamaan Stefan-Boltzman didapatkan nilai $5800 \mathrm{k}$. Jarak antara Bumi dan Matahari yang dihitung berdasarkan metode paralaks geosentrik menghasilkan nilai 149,5 juta kilometer. ${ }^{9}$

9S. Eka Gautama, Astronomi dan Astrofisika (Makassar: t.p., 2010), h. 158. 
Dalam pergerakan semunya yang diakibatkan pergerakan rotasi dan revolusi bumi, matahari senantiasa bergerak dari satu titik ke titik yang lainnya, dan akan kembali kepada titik semula. Matahari akan tepat berada di daerah khatulistiwa / equator bumi pada dua tanggal dalam dua bulan, yaitu tanggal 21 Maret dan 23 September. Pergerakan matahari dari khatulistiwa ke arah utara akan terjadi pada bulan Maret sampai dengan September, dan akan berada pada titik paling utara pada tanggal 21 Juni. Kemudian matahari akan bergerak ke arah selatan dimulai dari bulan September setelah melintasi titik khatulistiwa sampai dengan Maret. Pada titik terjauh di sebelah selatan, matahari akan berada pada tanggal 22 Desember dan akan kembali ke titik awal.10 Keadaan ini senantiasa bergerak terus menerus sehingga mengakibatkan panjang siang dan malam tidak tetap, terkadang panjang siang dan malam sama dan terkadang pula berbeda, siang lebih lama daripada malam, atau sebaliknya malam lebih lama daripada siang. Hal ini disebabkan karena pergerakan bumi yang dikenal dengan rotasi dan revolusi.

Firman Allah dalam surat al-Furqān ayat 61:

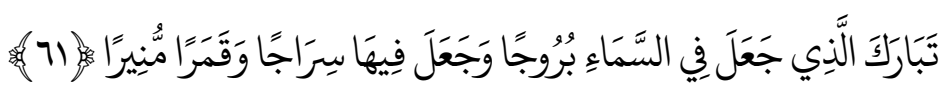

"Maha suci Allah yang menjadikan di langit gugusan-gugusan bintang dan Dia menjadikan juga padanya matahari dan bulan yang bercahaya."

Bumi merupakan benda langit yang termasuk anggota tata surya. Planet ini tempat tinggal yang ramah bagi makhluk hidup, sehingga ia tidak memancarkan sinar dalam pusatnya tetapi ia menerima panas dari bintang terdekatnya yaitu matahari. Bumi yang berbentuk bulat elips senantiasa bergerak dalam porosnya yang dikenal dengan rotasi dan bergerak dalam garis edarnya yang disebut revolusi. Akibat pergerakan ini, bagian permukaan bumi akan mengalami perubahan siang dan malam pada setiap harinya. Hal ini merupakan salah satu tanda yang dijadikan acuan waktu oleh manusia dan menunjukkan bahwa matahari memiliki posisi strategis bagi anggota planet tata surya, khususnya Bumi tempat kehidupan berada. Hal ini merupakan sebuah tanda keagungan penciptanya. Allah berfirman dalam surat al-Isrā ayat 12:

\footnotetext{
${ }^{10}$ Encep Abdul Rojak, "Hisab Arah Kiblat menggunakan Rubu' Mujayyab (Studi Pemikiran Muh. Ma'sum bin Ali dalam kitab Al-Durūs Al-Falakiyyah)", Skripsi (tidak dipublikasikan), (Semarang: IAIN Walisongo, 2011), h. 47.
} 


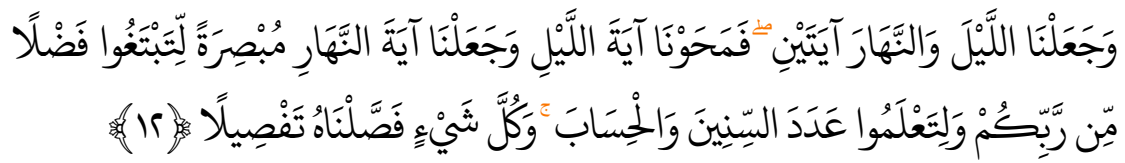

"Dan Kami jadikan malam dan siang sebagai dua tanda, lalu Kami hapuskan tanda malam dan Kami jadikan tanda siang itu terang, agar kamu mencari kurnia dari Tuhanmu, dan supaya kamu mengetahui bilangan tahun-tahun dan perhitungan. dan segala sesuatu telah Kami terangkan dengan jelas."

Terjadinya siang dan malam merupakan suatu karunia Allah yang disebabkan karena pergerakan bumi terhadap pusat tata surya yaitu matahari. Bentuk bumi yang bulat menyebabkan berbedanya daerah yang dapat menerima pancaran sinar dari matahari. Bagian belahan bumi yang menerima sinar matahari, pada saat yang bersamaan akan ditemukan bagian bumi yang tidak menerima sinar matahari dan terjadi gelap gulita. Hal ini disebabkan karena kedudukan bumi terhadap matahari. Fenomena alam ini mengandung pelajaran dan hikmah bagi manusia, yaitu dapat dijadikan acuan dalam satuan waktu, dan juga menjadi dasar perhitungan astronomis, ilmu pengetahuan dan tanggal yang menyempurnakan bilangan tahun.

Waktu salat didasarkan kepada fenomena alam, yaitu posisi matahari terhadap bumi. Misalnya QS Hūd ayat 114 terdapat kata tarafayinnahār yang bermakna kedua tepi siang dan zulafan min al-lail yang bermakna bahagian permulaan malam. Makna kedua tepi siang yaitu waktu pagi dan petang. Di dalamnya terdapat 3 waktu salat, yaitu Subuh, Zuhur, dan Asar. Pada sebagian permulaan malam terdapat dua watu salat, yaitu Magrib dan Isya. Kedua kata ini merupakan petunjuk pelaksanaan waktu salat wajib yang didasarkan kepada fenomena alam. Fenomena ini dihasilkan oleh posisi matahari terhadap bumi. Waktu pagi untuk suatu tempat yaitu ketika matahari akan terbit dan waktu petangnya ditandai dengan posisi matahari akan segera terbenam, sehingga posisi matahari semakin rendah setelah melewati meridian tempat tersebut. Hal ini menunjukkan bahwa kedudukan matahari terhadap penentuan awal waktu salat wajib merupakan sesuatu yang urgen. Oleh karena itu, dalam menghitung awal waktu salat harus mengetahui data-data matahari untuk menentukan posisinya. ${ }^{11}$

\footnotetext{
11Ismail, "Metode Penentuan Awal Waktu Salat Dalam Perspektif Ilmu Falak", Jurnal Ilmiah Islam Futura, Vol. 14, No. 2, Februari 2015, h. 225.
} 


\section{Waktu Zuhur}

Awal waktu duhur dimulai sesaat setelah matahari berkulminasi dan melintasi garis meridian tempat. Ketika matahari sudah melewati garis meridian suatu tempat, maka kedudukan matahari sudah berada di bagian langit barat, maka bagi tempat tersebut sudah masuk waktu Zuhur. Waktu salat ini akan berakhir ditandai dengan bayangan suatu benda yang disinari oleh matahari yang panjangnya sama dengan aslinya, ditambah dengan panjang bayangan pada saat matahari melintasi meridian/zawāl. ${ }^{12}$

\section{Waktu Asar}

Awal waktu salat Asar ditandai dengan panjang bayangan benda lebih panjang dari aslinya, dan akan berakhir ketika matahari terbenam di langit barat. Menurut jumhur ulama, awal waktunya dimulai dengan panjang bayangan suatu benda sama dengan aslinya dan ditambah dengan bayangan pada saat zawal. Masuknya waktu Asar merupakan tanda berakhirnya waktu salat duhur. Menurut Abu Hanifah, awal waktu Asar dimulai ketika panjang bayangan suatu benda dua kali dari panjang aslinya. Waktu Asar berakhir ketika matahari akan terbenam, sekira masih bisa melaksanakan satu raka'at di awal salatnya, maka itu termasuk waktu asar. ${ }^{13}$ Waktu salat Asar disebut juga dengan istilah salat wusțā, sebagaimana firman Allah di dalam al-Qur'ān surat al-Baqarah ayat 238.

\section{Waktu Magrib}

Secara bahasa, Magrib berasal dari ghoroba-yaghrubu yang memiliki arti pergi atau terbenam. Yakni terbenamnya matahari dari langit siang ke langit malam untuk suatu tempat tertentu. Dalam bahasa lain, terbenam matahari berarti perpindahan matahari dari busur langit siang kepada busur langit malam. Ulama sepakat bahwa awal waktu Magrib dimulai saat matahari terbenam, yaitu ketika seluruh piringan matahari, terutama bagian atas sudah berada di bagian busur malam. Waktu Magrib akan berakhir seiring masuknya

\footnotetext{
12Abū Mālik Kamāl bin al-Sayyid Sālim. Șahīh Fiqh al-Sunnah Waadillatuh, Wataudịh Madhāhib Aimmah. Juz I (Mesir: Maktabah al-Taufiqiyyah, 2003), h. 237.

13Abū Mālik Kamāl bin Al-Sayyid Sālim, Șahīh Fiqh al-Sunnah Waadillatuh, h. 239.
} 
waktu Isya yaitu hilangnya mega merah di langit barat. Namun terjadi silang pendapat diantara para ulama terkait akhir daripada waktu Magrib, ${ }^{14}$ yaitu:

a. Imam Syafi'i, Imam Malik, dan al-Awzā’i mengemukakan pendapat bahwa waktu Magrib itu hanya sebentar dengan rentang waktu yang sangat singkat. Waktu Magrib dideskripsikan sepanjang rentang waktu sejak orang melaksanakan bersuci/wudhu, kemudian merapihkan pakaian yang dapat menutup aurat ketika akan salat, kemudian mengumandangkan adzan ketika matahari terbenam, dan diakhiri dengan salat Magrib 3 rakaat. Setelah selesai salat, maka waktu Magrib telah berakhir sebagaimana rentang waktu dari deskripsi di atas. Ini menunjukkan betapa singkatnya waktu Magrib, apabila dikalkulasikan dalam bentuk waktu tidak akan lebih dari 30 menit.

b. Pendapat kedua yang di pegang oleh al-Thauri, Imam Ahmad, Ishāq, Abu Thaur dan sebagian Syafi'iyah, menyampaikan bahwa akhir daripada waktu Magrib yaitu ditandai dengan hilangnya mega merah di langit sebelah barat. Rentang waktu untuk pendapat kedua ini lebih lama dan memiliki kriteria yang jelas, yaitu ditandai dengan fenomena alam yang secara umum setiap hari pasti terjadi. Apabila cuaca cerah, fenomena ini akan mudah diamati di langit barat setelah matahari terbenam.

\section{Waktu Isya}

Kata Isya bermakna sebuah nama untuk menyebut permulaan gelap dari Magrib kepada 'atamah, sehingga salat ini disebut salat Isya. Awal waktu Isya dimulai ketika waktu Magrib sudah habis, yaitu ketika mega merah di langit barat sudah hilang. Dengan hilangnya mega merah, waktu Magrib sudah habis dan masuknya waktu Isya. Waktu salat ini memiliki rentang yang panjang, namun ada perbedaan pendapat tentang waktu akhirnya. Nilai sudut matahari yang terlihat dari cahaya senja berdasarkan pengamatan menggunakan $S k y$ Quality Meter (SQM) menunjukkan cahayanya fluktuatif dan tidak konstan.15 Diantara pendapat tersebut adalah: Pertama, sebagian ulama berpendapat bahwa waktu salat Isya hanya sampai pada sepertiga malam terakhir.

${ }^{14}$ Ibid, h. 242.

15 Nur Nafhatun Md Shariff, Amran Muhammad, Mohd Zambri Zainuddin, and Zety Sharizat Hamidi, The Application of Sky Quality Meter at Twilight for Islamic Prayer Time, International Journal of Applied Physics and Mathematics, Vol. 2, No. 3, May 2012, h. 144. 
Pendapat ini dipegang oleh imam Syafi'i dalam pendapat barunya/qawl jadìd, Abu Hanifah, dan Malik. Kedua, Pendapat kedua menyampaikan bahwa akhir daripada pelaksanaan salat Isya adalah pada pertengahan malam, yaitu kurang lebih terjadi pada pukul 24.00. Ketiga, Pendapat terakhir menyampaikan bahwa akhir waktu Isya sampai dengan terbit fajar shadiq. Pendapat terakhir ini lebih global dan memiliki rentang yang lama. Terbitnya fajar șādiq merupakan tanda masuknya waktu Subuh.

\section{Waktu Subuh}

Waktu Subuh sering juga disebut sebagai salat fajar. Fajar secara bahasa adalah al-Shafaq bermakna mega. Fenomena fajar di langit terjadi di langit timur sebelum matahari terbit. Terdapat dua macam fajar, yaitu fajar kädhib dan fajar șādiq. Fajar kādhib adalah fajar dengan ditandai munculnya cahaya putih yang memanjang yang muncul dari penjuru langit, dalam waktu tidak lama kemudian hilang. Adapun fajar sādiq yaitu seberkas cahaya putih yang menyebar yang berasal dari ufuk ke langit, kemudian bertambah dan bertambah, sehingga keadaan langit semakin cerah sampai dengan terbitnya matahari. Ketika posisi matahari semakin dekat dengan ufuk timur yang menandakan akan terbit matahari, maka fajar șādiq ini akan semakin bertambah. Fajar yang menjadi acuan dalam masuknya awal waktu Subuh yaitu fajar șädiq. Ketinggian matahari ketika fajar șādiq di Indonesia ditetapkan -20 $0^{\circ}$, namun pada kenyataannya perlu dianalisa lebih lanjut.16 Jadi awal waktu Subuh ditandai dengan terbitnya fajar șādiq di langit sebelah timur. Akhir daripada waktu salat Subuh ditandai dengan terbitnya matahari. Matahari dinyatakan terbit ketika piringan atasnya sudah melintasi ufuk suatu tempat.

\section{Koreksi Ketinggian Tempat Terhadap Posisi Matahari}

Permukaan daratan di muka bumi ini relatif dan tidak semuanya datar. Rata-rata terdapat dataran tinggi dan rendah. Ada bagian yang berbukit dan ada juga yang datar tapi diawali dengan dataran tinggi. Kedataran dan ketinggian suatu tempat di permukaan bumi ini diukur dengan menggunakan referensi kedataran air laut, sehingga disebut dengan istilah mean sea level

\footnotetext{
${ }^{16}$ Moh. Afif Amrulloh, "Penentuan Awal Waktu Salat Subuh Menurut Kementerian Agama dan Aliran Salafi". Jurisdictie: Jurnal Hukum dan Syariah, Volume 2, Nomor 2, Desember 2011, h. 120.
} 
atau di atas permukaan laut (dpl). Keadaan tempat yang datar atau tinggi akan berpengaruh terhadap acuan ufuk masing-masing tempat. Semakin tinggi suatu tempat, maka semakin besar nilai kerendahan ufuk yang dihasilkan. ${ }^{17}$ Tinggi tempat secara geodetik yang dinotasikan dengan (h) disebut sebagai jarak titik yang bersangkutan dari ellipsoid referensi di dalam arah garis normal terhadap ellipsoid referensi tersebut. ${ }^{18}$

Ketinggian tempat dikenal juga dengan istilah beda tinggi, yaitu beda nilai ketinggian antara dataran yang dijadikan referensi yaitu diatas permukaan laut dengan tempat tertentu. Untuk menentukan nilai ketinggian tempat bisa dilakukan dengan beberapa cara, ${ }^{19}$ yaitu: Pertama, sifat datar. Istilah ini memiliki arti konsep penentuan beda tinggi antara dua titik atau lebih dengan garis referensi horizontal yang diarahkan pada rambu-rambu secara vertikal. Alat ukur yang digunakan adalah penyipat datar atau waterpas. Keduanya merupakan alat yang mudah dijumpai dan cara penggunaannya tidak terlalu rumit.

Kedua, takhimetrik. Metode ini menggunakan data lapangan untuk menghitung jarak mendatar dan vertikal dengan bacaan rambu ukur yang terdapat pada alat reduksi sistem ini. Beberapa alat yang digunakan dalam metode ini adalah busur stadia Beaman, reduksi takhimeter otomatis dari Hamer-Fennel, dan reduksi takhimetri "Wild RDS". Dengan menggunakan metode ini, maka nilai beda tinggi dapat diketahui dengan baik dan akurat. Apabila terjadi kesalahan pada nilai akhir hal itu bisa disebabkan kesalahan penggunaan alat, human error dan kesalahan yang disebabkan dari alam sekitar.

Ketiga, trigonometrik. Pengukuran beda tinggi dengan cara ini merupakan sebuah proses penentuan beda tinggi dengan cara mengukur sudut miring atau sudut vertikalnya dengan jarak yang diketahui, yang dapat diukur dengan alat teodolit. Teodolit adalah alat ukur yang digunakan untuk mengukur sudut

17M. Sayuthi Ali, Ilmu Falak I (Jakarta: Raja Grafindo Persada, 1997), h. 41.

${ }^{18}$ Eddy Prahasta, Konsep-konsep Dasar Sistem Informasi Geografis (Bandung: Penerbit Informatika, 2002), h. 140.

${ }^{19}$ Yuyun Hudhoifah, "Formulasi Penentuan Awal Waktu Salat yang Ideal (Analisis terhadap Urgensi Ketinggian Tempat dan Penggunaan Waktu Ikhtiyat untuk Mengatasi Urgensi Ketinggian Tempat dalam Formulasi Penentuan Awal Waktu Salat)", Skripsi (tidak dipublikasikan) (Semarang: IAIN Walisongo, 2011), h. 55. 
kedudukan benda langit dalam tata koordinat horizontal yaitu tinggi dan azimut. $^{20}$

Keempat, barometrik. Barometer merupakan sebuah alat untuk mengukur variasi tekanan udara, karena variasi tekanan udara merupakan salah satu indikator yang berkaitan dengan beda tinggi. Tekanan udara pada permukaan air laut adalah $1 \mathrm{~kg} / \mathrm{cm}^{2}$ dan berkurang jika ketinggiannya bertambah. Perbedaan $1 \mathrm{~cm}^{2}$ air raksa akan sebanding dengan kenaikan tinggi 108 meter. Alat yang dapat digunakan dengan metode ini adalah altimeter.

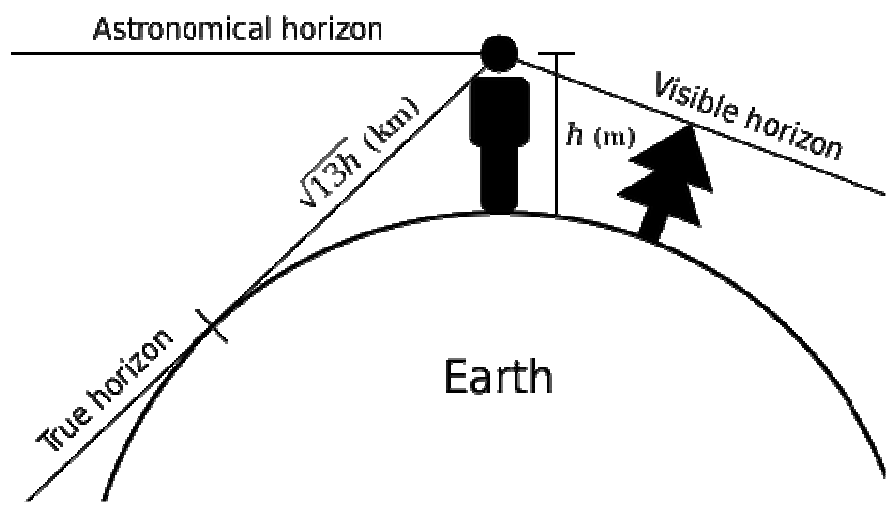

Gambar 1.

Kerendahan ufuk untuk suatu tempat dengan ketinggian 0 meter dpl.

Ketinggian suatu tempat akan berpengaruh terhadap horizon suatu tempat. Dalam istilah lainnya disebut juga cakrawala, kaki langit, atau ufuk. Horizon didefinisikan sebagai garis yang memisahkan bumi dari langit sehingga garis itu terlihat seperti penghubung antara langit dan bumi. Setiap tempat di bumi memiliki horizon tersendiri. Terdapat 3 macam horizon, yaitu: a) Horizon astronomi (astronomical horizon), b) Horizon visibel (visible horizon), c) Horizon sejati / sebenarnya (true horizon).

Pada gambar 1, diilustrasikan ketinggian tempat sama dengan 0 meter dpl, sehingga ufuk hakikinya / true horizon setinggi orangnya. Semakin tinggi suatu

20Muhyiddin Khazin, Kamus Ilmu Falak (Jogjakarta: Buana Pustaka, 2005), h. 83. 
tempat terhadap ufuk, maka semakin dalam juga ufuk hakikinya. Apabila benda langit yang dilihat itu adalah matahari, semakin tinggi tempat, maka ia akan semakin lama mendapatkan sinar matahari. ${ }^{21}$

\section{Urgensi Koreksi Ketinggian Tempat terhadap Waktu Salat}

Salah satu tempat yang memiliki data ketinggian tempat yang relatif besar adalah kota Bandung. Kota ini merupakan tempat yang berada di pusat pemerintahan Provinsi Jawa Barat. Secara geografis, daerah ini terletak pada bujur $107^{\circ} 36^{\prime} \mathrm{BT}$ dan lintang $-6^{\circ} 55^{\prime} \mathrm{LS}$. Luas wilayah kota Bandung kurang lebih 16.731 hektar. Panjang wilayah yang terbentang dari timur ke barat lebih dari $18 \mathrm{~km}$, dan lebar wilayah dari utara ke selatan secara garis lurus terhitung kurang lebih $12 \mathrm{~km}$.

Secara topografi, kota Bandung memiliki keragaman permukaan tanah. Terdapat dataran yang rendah dan tinggi dalam keadaan tidak merata. Di kota ini, dataran terrendah memiliki ketinggian variatif diantara 600 - 700 meter di atas permukaan laut (dpl). Tempat yang termasuk paling rendah ini didominasi oleh lokasi yang berada di bagian selatan, kecuali daerah pegunungan bagian selatan. Kemudian dataran yang tertinggi untuk Kota Bandung berkisar 900 - 1000 meter dpl. Daerah ini didominasi oleh bagian utara Bandung yang memang termasuk daerah perbukitan dan pegunungan. Jadi Kota Bandung berada pada ketinggian tempat antara $600 \mathrm{~m}$ s.d 1000 meter dpl dan rata-rata ketinggiannya adalah 768 meter dpl. ${ }^{22}$

Ada beberapa data yang hanya digunakan dalam perhitungan salah satu waktu salat saja. Waktu-waktu yang lainnya tidak memiliki pengaruh yang signifikan, sehingga data tersebut diabaikan. Diantara data yang digunakan secara khusus untuk salah satu waktu salat saja adalah data ketinggian tempat. Data ini tidak digunakan pada awal waktu salat lainnya, kecuali pada perhitungan awal waktu salat magrib. Bandung merupakan daerah yang memiliki ketinggian tempat di atas 700 meter dpl, maka data koreksi ketinggian tempat harus dipertimbangkan dan masuk dalam perhitungan. ${ }^{23}$

\footnotetext{
21https://tdjamaluddin.wordpress.com/2017/01/04/jawaban-atas-pertanyaan-penggemardongeng-fe-bumi-datar-serial-3/, diakses pada tanggal 22/09/2017.

22https://ppid.bandung.go.id/profil-kota-bandung/, diakses pada 3 Juni 2017.

23Wawancara Encup Supriatna, Bandung, 1 Mei 2017.
} 
Ketinggian tempat yang ekstrim, misalkan di atas 500 meter dpl, tidak akan berpengaruh kepada perhitungan waktu salat lainnya kecuali Magrib. Awal waktu Isya yang memang posisinya setelah Magrib, namun untuk data ketinggian mataharinya sudah ditetapkan yaitu sekitar $-18^{\circ}$ dan tanpa mempertimbangkan ketinggian tempat.24

Pentingnya penggunaan data koreksi tempat untuk jadwal salat Kota Bandung disampaikan juga oleh ketua BHR Kota Bandung, Maftuh Kholil. Ia menyampaikan bahwa secara realitas, tidak ada wilayah Bandung dengan ketinggian 0 meter dpl, tetapi ketinggiannya diatas 700 meter dpl. Jadi kalau menghitung jadwal salat Bandung dengan ketinggian $0 \mathrm{~m}$, itu artinya jadwal tersebut bukan untuk Bandung. Begitu juga apa disampaikan oleh Zulbaedah, dosen ilmu falak UIN Sunan Gunung Djati Bandung dan praktisi ahli falak Muhammadiyah Jawa Barat, menyampaikan bahwa koreksi ketinggian tempat ini sangat penting dimunculkan dalam perhitungan jadwal waktu salat kota Bandung. Ketinggian 700 meter dpl bukanlah ketinggian yang sedikit, itu merupakan ketinggian yang besar. Ini menunjukkan bahwa data ketinggian tempat harus diperhitungkan. ${ }^{25}$

Terdapat selisih yang signifikan antara jadwal yang dihitung dengan menggunakan ketinggian 0 meter dan data 700 meter dpl, khususnya untuk jadwal salat Magrib. Moedji Raharto menyampaikan bahwa selisih waktu antara dua perbedaan acuan tersebut sekitar 4 menit. Jadwal yang melakukan perhitungan dengan mengacu kepada 0 meter akan lebih cepat 4 menit dibandingkan dengan pembandingnya. Selisih ini tidak bisa disepelekan karena tergolong perbedaan yang besar, apalagi jika terjadi pada bulan Ramadhan. Sehingga kalau seandainya ada dua jadwal yang berkembang, maka akan terjadi ketimpangan yang sangat meresahkan masyarakat umum. Sebagaimana diketahui secara umum, Magrib merupakan waktu yang sangat dinanti dan awal daripada berbuka puasa. Muslim meyakini sebuah ajaran dari Rasulullah Saw tentang kebaikan yang terdapat pada menyegerakan berbuka puasa. Sehingga mayoritas umat Islam, ketika adzan Magrib berkumandang, mereka akan menyegerakan untuk berbuka, bukan saja karena kesunnahan

\footnotetext{
24Wawancara Hendro Setyanto, Bandung, 24 Januari 2017.

25Sidang penyusunan jadwal waktu salat 2017 yang diselenggarakan pada di Bandung, 21 Oktober 2016 oleh Badan Hisab dan Rukyat Daerah Prov. Jawa Barat.
} 
tetapi merupakan suatu kebutuhan. Fenomena ini memberikan pelajaran bahwa ketika terjadi kesalahan 1 menit saja dalam jadwal Magrib, maka hasilnya akan fatal dan bisa jadi secara syariat puasa umat Islam tidak sah, karena berbuka belum pada waktunya. ${ }^{26}$

Sama halnya dengan pendapat yang lain, Toto Supriyanto menjelaskan tentang pentingnya penggunaan koreksi ketinggian tempat untuk jadwal waktu salat. Ia menambahkan juga bahwa di dalam software Accurate Time yang dibuat oleh Odeh yang berasal dari Yordania, input data waktu salat untuk kota Bandung sudah menggunakan data ketinggian 715 meter dpl. Ini menunjukkan akan pentingnya penggunaan koreksi ketinggian tempat untuk perhitungan awal waktu salat. ${ }^{27}$ Untuk daerah yang tidak terletak persis di sisi pantai dengan ketinggian yang curam, maka penggunaan data koreksi ketinggian bisa dilakukan. Namun demikian, perlu dilakukan penelaahan lebih lanjut agar tepat. ${ }^{28}$

\section{Aritmatika Waktu Salat kota Bandung}

Waktu salat berlaku lokalitas sesuai data yang dimasukkan dalam perhitungan. Data lintang dan bujur yang menjadi referensi perhitungan menjadi dasar berlakunya jadwal salat tersebut. Ditambah dengan data-data lainnya seperti ketinggian tempat. Pada umumnya, aritmatika waktu salat ini bisa dihitung dengan menggunakan sistem pada windows yang tersedia, sehingga membentuk sebuah program yang praktis dan otomatis. Seperti program implementasi algoritma J. Meeus untuk program waktu salat. ${ }^{29} \mathrm{Di}$ bawah ini disajikan contoh perhitungan antara data perhitugan yang menggunakan data ketinggian tempat dan tidak. Dalam contoh ini, perhitungan untuk kota Bandung tanggal 1 September 2017.

Lintang $\quad:-06^{\circ} 57^{\prime}$ LS

26 Ibid.

27Wawancara Toto Supriyanto, Bandung, 1 Februari 2017.

28Wawancara Ahmad Nizar, Bandung, 19 April 2017.

${ }^{29}$ Isnaeni, Dede Muhammad. Fitri Mintarsih, Feri Fahrianto, Implementasi Algoritma Meeus Dalam Penentuan Waktu Salat Dan Pencarian Masjid Terdekat, Studia Informatika: Jurnal Sistem Informasi, 8(1), 2015, h. 3 
Bujur $\quad: 107^{\circ} 37^{\prime} \mathrm{BT}$

Bujur daerah $\quad: 105^{\circ}$

Tinggi Tempat : 750 meter dpl.

Data matahari

Deklinasi : $\quad 8^{\circ} 12^{\prime} 27^{\prime \prime}$

Perata waktu : -0 menit 1 detik

Menghitung waktu salat:

Data awal:

Merr Pass $\quad: 12--0 \mathrm{j} 0 \mathrm{~m} \mathrm{1dtk}=12 \mathrm{j} \mathrm{0m} \mathrm{1dtk}$

Interpolasi $\quad:\left(107^{\circ} 57^{\prime}-105^{\circ}\right) / 15=0 \mathrm{j} 11 \mathrm{~m} 48 \mathrm{dtk}$

Ketinggian matahari

Duhur : tidak diperhitungkan

Asar $\quad:$ Cotan $\mathrm{h}_{\mathrm{o}}=\tan [\varphi-\delta]+1$

Cotan $\mathrm{h}_{\mathrm{o}}=\tan \left[-06^{\circ} 57^{\prime}-8^{\circ} 12^{\prime} 27^{\prime \prime}\right]+1$

$\mathrm{h}_{\mathrm{o}}=38^{\circ} 11^{\prime} 50^{\prime \prime}$

Magrib

$=\mathrm{h}_{\mathrm{o}}=-(\operatorname{Ref}+\mathrm{sd}+\mathrm{ku})$

$\mathrm{Ku}=0^{\circ} 1,76^{\prime} \mathrm{x} \sqrt{\mathrm{TT}}$

$\mathrm{Ku}=0^{\circ} 1,76^{\prime} \mathrm{x} \sqrt{ } 750$

$\mathrm{Ku}=0^{\circ} 48^{\prime}$

$\mathrm{h}_{\mathrm{o}}=-\left(0^{\circ} 34^{\prime}+0^{\circ} 16^{\prime}+0^{\circ} 48^{\prime}\right)$

$\mathrm{h}_{0}=-1^{\circ} 38^{\prime}$

Isya $\quad:-18^{\circ}$

Subuh $\quad:-20^{\circ}$

Menghitung sudut waktu matahari

1. Zuhur

Sudut waktu matahari untuk duhur tidak diperhitungkan

2. Asar

Data ini dicari dengan rumus: 
$\operatorname{Cos} \mathrm{t}_{\mathrm{o}}=\sin \mathrm{h}_{\mathrm{o}} \div \cos \varphi^{\mathrm{x}} \div \cos \delta-\tan \varphi^{\mathrm{x}} \mathrm{x} \tan \delta$

$\operatorname{Cos} \mathrm{t}_{0}=\sin 38^{\circ} 11^{\prime} 50^{\prime \prime} \div \cos -06^{\circ} 57^{\prime} \div \cos 8^{\circ} 12^{\prime} 27^{\prime \prime}-\tan -06^{\circ} 57^{\prime} \mathrm{x}$ $\tan 8^{\circ} 12^{\prime} 27^{\prime \prime}$

$\mathrm{t}_{0}=49^{\circ} 41^{\prime} 9,6^{\prime \prime}$

dijadikan waktu dengan cara $=49^{\circ} 41^{\prime} 9,6^{\prime \prime} / 15$

$=3 \mathrm{j} 18 \mathrm{~m} 45 \mathrm{dtk}$

3. Magrib (dengan ketinggian)

Data ini dicari dengan rumus:

Cos $\mathrm{t}_{0}=\sin \mathrm{h}_{0} \div \cos \varphi^{\mathrm{x}} \div \cos \delta-\tan \varphi^{\mathrm{x}} \mathrm{x} \tan \delta$

$\cos t_{0}=\sin -1^{\circ} 38^{\prime} \div \cos -06^{\circ} 57^{\prime} \div \cos 8^{\circ} 12^{\prime} 27^{\prime \prime}-\tan -06^{\circ} 57^{\prime} \times \tan 8^{\circ}$ $12^{\prime} 27^{\prime \prime}$

$\mathrm{t}_{\mathrm{o}}=90^{\circ} 39^{\prime} 28,8^{\prime \prime}$

dijadikan waktu dengan cara $=90^{\circ} 39^{\prime} 28,8^{\prime \prime} / 15$

$$
=6 \mathrm{j} 2 \mathrm{~m} 38 \mathrm{dtk}
$$

Magrib (tanpa ketinggian tempat)

Data ini dicari dengan rumus:

$\operatorname{Cos} t_{0}=\sin h_{0} \div \cos \varphi^{\mathrm{x}} \div \cos \delta-\tan \varphi^{\mathrm{x}} \mathrm{x} \tan \delta$

$\operatorname{Cos} t_{0}=\sin -1^{\circ} \div \cos -06^{\circ} 57^{\prime} \div \cos 8^{\circ} 12^{\prime} 27^{\prime \prime}-\tan -06^{\circ} 57^{\prime} \times \tan 8^{\circ} 12^{\prime}$ 27"

$\mathrm{t}_{\mathrm{o}}=90^{\circ} 0^{\prime} 37,41^{\prime \prime}$

dijadikan waktu dengan cara $=90^{\circ} 0^{\prime} 37,41^{\prime \prime} / 15$

$$
=6 \mathrm{j} 0 \mathrm{~m} 03 \mathrm{dtk}
$$

4. Isya

Data ini dicari dengan rumus:

Cos $\mathrm{t}_{0}=\sin \mathrm{h}_{0} \div \cos \varphi^{\mathrm{x}} \div \cos \delta-\tan \varphi^{\mathrm{x}} \mathrm{x} \tan \delta$

$\operatorname{Cos} t_{0}=\sin -18^{\circ} \div \cos -06^{\circ} 57^{\prime} \div \cos 8^{\circ} 12^{\prime} 27^{\prime \prime}-\tan -06^{\circ} 57^{\prime} \times \tan 8^{\circ} 12^{\prime}$ $27 "$

$\mathrm{t}_{0}=107^{\circ} 55^{\prime} 12^{\prime \prime}$

dijadikan waktu dengan cara $=107^{\circ} 55^{\prime} 12^{\prime \prime} / 15$

$$
=7 \mathrm{j} 11 \mathrm{~m} 40 \mathrm{dtk}
$$

5. Subuh

Data ini dicari dengan rumus:

Cos $\mathrm{t}_{0}=\sin \mathrm{h}_{0} \div \cos \varphi^{\mathrm{x}} \div \cos \delta-\tan \varphi^{\mathrm{x}} \mathrm{x} \tan \delta$

$\operatorname{Cos} t_{0}=\sin -20^{\circ} \div \cos -06^{\circ} 57^{\prime} \div \cos 8^{\circ} 12^{\prime} 27^{\prime \prime}-\tan -06^{\circ} 57^{\prime} \times \tan 8^{\circ} 12^{\prime}$ $27 "$ 
$\mathrm{t}_{\mathrm{o}}=109^{\circ} 57^{\prime}$

dijadikan waktu dengan cara $=109^{\circ}$ 57' $/ 15$

$$
=7 \mathrm{j} 19 \mathrm{~m} 48 \mathrm{dtk}
$$

Menghitung awal waktu salat

1. Duhur

MP $=12 \mathrm{j} 00 \mathrm{~m} \mathrm{1dtk}$

Interpolasi $=0 \mathrm{j} 11 \mathrm{~m} 48 \mathrm{dtk}-$

11j 48m 13dtk

2. Asar

$\mathrm{MP}=12 \mathrm{j} 00 \mathrm{~m} 1 \mathrm{dtk}$

$\mathrm{t}_{\mathrm{o}} \quad=03 \mathrm{j} 18 \mathrm{~m} \mathrm{45 \textrm {dtk } +}$

15j $18 \mathrm{~m} 46 \mathrm{dtk}$

Interpolasi $=0$ 0 $11 \mathrm{~m} 48 \mathrm{dtk}-$

15j 06m 58dtk

3. Magrib (dengan ketinggian)

MP $=12 \mathrm{j} 00 \mathrm{~m} 1 \mathrm{dtk}$

$\mathrm{t}_{\mathrm{o}} \quad=6 \mathrm{j} 02 \mathrm{~m} \mathrm{38dtk+}$

18j 02m 39dtk

Interpolasi $=\underline{0 \mathrm{j} 11 \mathrm{~m} 48 \mathrm{dtk}-}$

17j 50m 51dtk

Magrib (tanpa ketinggian)

$\mathrm{MP}=12 \mathrm{j} 00 \mathrm{~m} 1 \mathrm{dtk}$

$\mathrm{t}_{\mathrm{o}} \quad=6 \mathrm{j} 00 \mathrm{~m} \mathrm{03dtk}+$ 18j 00m 04dtk

Interpolasi $=\underline{0 \mathrm{j} 11 \mathrm{~m} 48 \mathrm{dtk}-}$ 17j 48m 16dtk

4. Isya

$$
\begin{array}{ll}
\text { MP } & =12 \mathrm{j} 00 \mathrm{~m} \mathrm{1dtk} \\
t_{0} & =\frac{07 \mathrm{j} 11 \mathrm{~m} \mathrm{40dtk+}}{19 \mathrm{j} 11 \mathrm{~m} 41 \mathrm{dtk}} \\
\text { Interpolasi } & =\frac{0 \mathrm{j} 11 \mathrm{~m} 48 \mathrm{dtk}-}{18 \mathrm{j} 59 \mathrm{~m} 53 \mathrm{dtk}}
\end{array}
$$

5. Subuh

MP $=12 \mathrm{j} 00 \mathrm{~m} 1 \mathrm{dtk}$ 
Encep Abdul Rojak, Amrullah Hayatudin, Muhammad Yunus

$$
\begin{array}{ll}
\mathrm{t}_{\mathrm{o}} & =\frac{07 \mathrm{j} 19 \mathrm{~m} 48 \mathrm{dtk}-}{04 \mathrm{j} 40 \mathrm{~m} 13 \mathrm{dtk}} \\
\text { Interpolasi } & =\frac{0 \mathrm{j} 11 \mathrm{~m} \mathrm{48dtk}-}{04 \mathrm{j} 28 \mathrm{~m} \mathrm{25dtk}}
\end{array}
$$

Rekap:

\begin{tabular}{cccccc}
\hline \multirow{2}{*}{ Duhur } & \multirow{2}{*}{ Asar } & \multicolumn{2}{c}{ Magrib } & \multirow{2}{*}{ Isya } & \multirow{2}{*}{ Subuh } \\
& & Plus & Tanpa & & \\
\cline { 1 - 4 } $11: 48$ & $15: 07$ & $17: 51$ & $17: 48$ & $18: 59$ & $04: 28$ \\
\hline
\end{tabular}

Perhitungan awal waktu salat di atas digunakan untuk kota Bandung pada tanggal 1 September 2017. Data-data tersebut mencakup data matahari dan geografis bumi. Setelah dilakukan perhitungan, hasil akhir tidak ditambahkan dengan ihtiyat, sehingga hasil waktu salatnya masih utuh sesuai dengan perhitungan. Dari hasil akhir perhitungan di atas dapat diketahui bahwa ada waktu yang terpengaruhi oleh data ketinggian tempat dan ada pula yang tidak, sehingga pengaruh daripada koreksi ketinggian tempat terhadap fikih waktu salat dapat dikategorikan menjadi dua bagian, yaitu:

\begin{tabular}{clcc}
\hline No. & Waktu Salat & $\begin{array}{c}\text { Pengaruh } \\
\text { Ketinggian }\end{array}$ & Selisih \\
\hline 1. & Subuh & Tidak & 0 menit \\
2. & Duhur & Tidak & 0 menit \\
3. & Asar & Tidak & 0 menit \\
4. & Magrib & Ya & 3 menit \\
5. & Isya & Tidak & 0 menit \\
\hline
\end{tabular}

Terdapat satu awal waktu salat yang terpengaruh oleh koreksi ketinggian tempat, yaitu salat Magrib. Awal waktu salat Subuh, Duhur, Asar, dan Isya tidak terpengaruh oleh koreksi ketinggian suatu tempat. Suatu tempat dengan kondisi geografis dataran dan perbukitan, ketika berada dalam satu zona waktu yang sama dan satu wilayah, seperti Bandung, Sumatera, Papua, dan beberapa daerah lainnya, maka waktu salat selain Magrib diawali pada waktu yang sama. 
Untuk perhitungan awal waktu salat Magrib, bagi suatu tempat yang tidak datar, memiliki perbukitan yang beragam, maka data koreksi ketinggian tempat harus diperhitungkan. Selisih 3 menit merupakan selisih yang terbilang banyak dan bisa jadi sebagai penentu keabsahan dalam melaksanakan ibadah, baik salat maupun puasa. Bandung dengan ketinggian tempat di atas 700 meter dpl, berdasarkan kepada data perhitungan, terdapat selisih yang signifikan antara jadwal salat yang mereferensi kepada 0 meter dpl dan 700 meter dpl. Hal ini disebabkan karena beda ufuk antara tempat dengan ketinggian 0 meter dpl dengan 700 meter dpl.

\section{Kesimpulan}

Kota Bandung termasuk kota dengan kedataran tempat yang variatif. Kota ini memiliki data ketinggian tempat di atas 700 meter dpl. Setelah dilakukan perbandingan perhitungan antara 0 meter dpl dan 750 meter dpl, terjadi selisih untuk waktu salat Magrib. sedangkan waktu-waktu salat lainnya, Subuh, Duhur, Asar, dan Isya tidak terpengaruh oleh koreksi ketinggian tempat. Selisih waktu antara salat Magrib yang menggunakan data ketinggian tempat dengan tidak adalah sekitar 3 menit. Perbedaan waktu ini apabila terjadi pada waktu Ramadhan, sangatlah riskan dan krusial, dan bahkan bisa menyebabkan kesalahan umat Islam dalam mengawali berbuka puasa. Ibadah puasa bisa jadi tidak sah apabila berbuka bukan pada tempatnya. Para ulama ilmu falak di Bandung pun mengharuskan perhitungan menggunakan data real kota Bandung, yaitu dengan memperhatikan data ketinggian tempat. Oleh karena itu, penting sekali perhitungan awal waktu salat, khususnya Magrib menggunakan data ketinggian tempat dalam proses perhitungannya.[a]

\section{DAFTAR PUSTAKA}

Admin, Geografi Kota Bandung, http://bandungaktual.com/2013/10/ geografi-kota-bandung.html, diakses tanggal 26 Nopember 2016.

Admin, Profil Kota Bandung (Online), (https://ppid.bandung.go.id/profil-kotabandung/, diakses tanggal 26 April 2017)

Amri, Tamhid, "Waktu Salat Perspektif Syar'i”. Asy-Syari'ah. Vol. 17 Nomor 1, Desember 2014. 
Amrulloh, Moh. Afif, "Penentuan Awal Waktu Salat Subuh Menurut Kementerian Agama dan Aliran Salafi". Jurisdictie, Jurnal Hukum dan Syariah, Volume 2, Nomor 2, Desember 2011.

Anugraha, Rinto, Mekanika Benda Langit, Yogyakarta: Universitas Gadjah Mada, 2012.

Azhari, Susiknan, Ilmu Falak Perjumpaan Khazanah Islam dan Sains Modern, Yogyakarta: Suara Muhammadiyah, 2007.

Darajat, Muhammad Nashiruddin, Abdul Fadlil, Sunardi, "Sistem Informasi Arah Kiblat Dan Jadwal Waktu Salat Berbasis Android", Jurnal Teknologi, Volume 9 Nomor 2, Desember 2016.

Djamaludin, T., https://tdjamaluddin.wordpress.com/ diakses pada tanggal 14 September 2016.

Hudhoifah, Yuyun, "Formulasi Penentuan Awal Waktu Salat yang Ideal (Analisis terhadap Urgensi Ketinggian Tempat dan Penggunaan Waktu Ikhtiyat untuk Mengatasi Urgensi Ketinggian Tempat dalam Formulasi Penentuan Awal Waktu Salat)", Skripsi (tidak dipublikasikan). Semarang: IAIN Walisongo, 2011.

Ismail, "Metode Penentuan Awal Waktu Salat dalam Perspektif Ilmu Falak", Jurnal Ilmiah Islam Futura. Vol. 14. No. 2, Februari 2015.

Isnaeni, Dede Muhammad, Fitri Mintarsih, Feri Fahrianto, "Implementasi Algoritma Meeus dalam Penentuan Waktu Salat dan Pencarian Masjid Terdekat", Studia Informatika: Jurnal Sistem Informasi, 8(1), 2015.

Jayusman, "Jadwal Sholat Hasil Konversi Koreksian Daerah: Antara Kepentingan Efisiensi dan Akurasi." Yudisia. Volume 5, Nomor 2, Desember 2015.

"Jadwal Waktu Salat Abadi", Khatulistiwa - Journal of Islamic Studies, Vol. 3 Nomor 1 Maret 2013

Kamāl, Abū Māilk bin al-Sayyid Sālim, Sahīh Fiqh al-Sunnah wa Adillatuh, Wataudīh Madhāhib Aimmah, Juz I, Mesir: Maktabah al-Taufiqiyah, 2003.

Khazin, M., Ilmu Falak dalam Teori dan Praktek. Yogyakarta: Buana Pustaka, 2007.

Muhammad bin Ismaīl, Șahīh al-Bukhāri. Mesir: Dār al-Álamiyyah, 2015.

Muslim, Abū al-Ḥusain bin Ḥajjaj al-Qushairi al-Naisābūri, Șahīh Muslim, t.tp: Maktabah Fayad, 2010. 
Prahasta, Eddy, Konsep-konsep Dasar Sistem Informasi Geografis. Bandung: Penerbit Informatika, 2002.

Rojak, Encep Abdul, "Hisab Arah Kiblat Menggunakan Rubu' Mujayyab: Studi Pemikiran Muh. Ma'sum bin Ali dalam Kitab al-Durūs al-Falakiyyah", Skripsi (tidak dipublikasikan), Semarang: IAIN Walisongo. 2011.

Sābiq, Sayyid, Fiqh al-Sunnah, Juz I, Beirut: Dar al-Fikr, t.th.

Shariff, Nur Nafhatun Md, Amran Muhammad, Mohd Zambri Zainuddin, and Zety Sharizat Hamidi, "The Application of Sky Quality Meter at Twilight for Islamic Prayer Time", International Journal of Applied Physics and Mathematics, Volume 2, No. 3, May 2012

al-Sha'rāwī, Muhammad Mutawali, Tafsir ayat al-Aḥkam, Juz I, Cairo: alMaktabah al-Taufiqiyah, t.th.

Wawancara dengan Ahmad Nizar, Bandung, 19 April 2017.

Wawancara dengan Encup Supriyatna, Bandung, 21 April 2017.

Wawancara dengan Toto Supriyanto, Bandung, 01 Februari 2017.

Wawancara dengan Hendro Setyanto, Bandung, 24 Januari 2017.

al-Zuhaili, Wahbah, Tafsìr al-Munīr, Jilid 11. Damsyiq: Dār al-Fikr, 2009. 
266 || Volume 27, Nomor 2, Oktober 2017 